\section{Determinants of Customer Inertia - An Investigation of Mobile Phone Services}

\author{
José Marcos Carvalho de Mesquita ${ }^{1}$ \\ ${ }^{1}$ University of Connecticut, Marketing Department, Stamford, USA \\ André Torres Urdan ${ }^{2}$ \\ ${ }^{2}$ Universidade Nove de Julho, Programa de \\ Pós-graduação em Administração, São Paulo, Brazil
}

\begin{abstract}
Purpose - In ongoing service sectors, some companies have high customer retention in spite of frequent consumer dissatisfaction and high complaint rates. This retention results from customer inertia. This paper aims to identify what influences this inertial behavior.
\end{abstract}

Design/methodology/approach - Two competing conceptual models were conceived: a Base Model, which considers mediating effects, and a Rival Model, which considers only the direct effects on customer inertia. A survey was undertaken in Brazil. Mobile phone customers were targeted. A questionnaire was built and data were collected online as well as in person. Structural equation modeling was applied.

Findings - Only direct effects on customer inertia were confirmed. The Rival Model outperformed the Base Model on a set of criteria (e.g., greater explanatory power for Customer Inertia and more simplicity). The Rival Model offers a moderate explanation $\left(\overline{\mathrm{R}}^{2}=0.370\right)$, some sound structural path coefficients, and appropriate psychometric properties for the latent constructs.

Originality/value - The paper complements and adds to existing research by evaluating customer inertia as an important outcome within ongoing service markets. Market isomorphism, a new concept, is included in the analysis. Results from a developing country are described, helping to generalize to a broader set of countries.

Keywords - Customer inertia, Switching avoidance, Antecedents, Mobile phone, Brazil.
Received on

10/09/2017

Approved on

$10 / 23 / 2018$

Responsible editor:

Profa. Dra Susana Costa

Evaluation process:

Double Blind Review

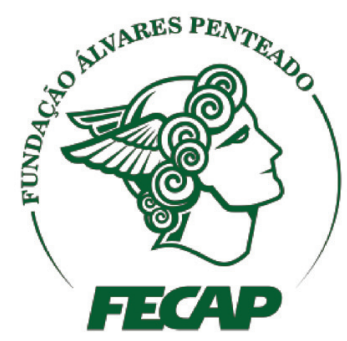

Review of Business Management 


\section{Introduction}

Relationship Marketing has provided many classic contributions around the world, such as the loyalty matrix (Dick \& Basu, 1994), the loyalty phases and ultimate loyalty (Oliver, 1997, 1999), and the roles of trust and commitment (Morgan \& Hunt, 1994; Garbarino \& Johnson, 1999; Sirdeshmukh, Singh, \& Sabol, 2002). This research stream permeates the Brazilian marketing academia (Barreto, Crescitelli, \& Figueiredo, 2015).

On the other hand, inertia influences customer retention even without any genuine relationship marketing initiative. However, the deficiency in terms of explaining customer inertia still persists (Khedhaouria, Thurik, Gurau, \& van Heck, 2016). D'Alessandro, Johnson, Gray, and Carter (2017, p.1) even say that "little is known about the antecedent drivers of inertia". The construct is misunderstood, and even undervalued by marketing researchers and professionals, despite it having been studied since the nineties (Assael, 1992; Bozzo, 2002; Ranaweera \& Neely, 2003; Yanamandram \& White, 2004, 2006, 2007; Wu, 2011).

Costumer inertia can be classified as spurious loyalty (Dick \& Basu, 1994), characterized by repeated purchases from the same supplier despite the lack of a favorable attitude towards it. In some sectors, especially those of ongoing services (such as fixed and mobile telephones, and credit cards), consumer inertia always appears. As a result, despite consumer dissatisfaction, disappointment, and high complaint rates, a company can maintain high customer retention rates (Zeelenberg \& Pieters 2004; Yanamandram \& White, 2004). Spurious loyalty is associated with the absence of a superior alternative. In some ongoing service sectors, there are alternatives (although few), yet their offerings, through the eyes of the clientele, appear to be equivalents. Customer inertia seems to be a consequence of an attitude of passiveness (no intention to change a behavior) because alternative providers are seen as quite similar and not satisfactory. Customer inertia could also be impacted by switching avoidance, a personal state characterized by resistance to change, and avoidance of new circumstances and agents. Moreover, when the customer fully and consistently enjoys the quality and is satisfied with the goods/services, inertia should be a rational reaction. This is a preliminary set of possible antecedents of customer inertia and others must be identified and tested. This reflection gives rise to our research question: What are the main determinants of customer inertia? Our objective is to evaluate antecedents of customer inertia as well as a possible mediating construct.

\section{Hypotheses Development and Conceptual Models}

This section i) reviews the literature on Customer Inertia and some of its potential antecedents, and ii) elaborates associated hypotheses that comprise two Conceptual Models.

\section{I Customer Inertia}

In physics, inertia is a property of matter that keeps an object in motion moving in the same direction or keeps an object at rest (stationary), unless an external force is applied on it (Young \& Freedman, 2008). In a broader view, inertia is the tendency of all objects in the universe to resist changes to their state of motion (stationary or moving), and to continue doing what they are doing (unless acted on by a greater outside force).

Inertia is also a relevant concept for many human phenomena, taken as a metaphor and associated with resistance to change. Decision inertia, for instance, is the "tendency to repeat previous choices independently of the outcome, which can give rise to perseveration in suboptimal choices" (Alós-Ferrer, Hügelschäfer, \& Li, 2016, p.1); that is, it is directly related to preference for consistency. People can be subject to inertia with respect to their attitudes and beliefs about themselves and the world, the emotions they feel, the decisions they make, and the actions they carry 
out, irrespective of previous beneficial or harmful consequences.

Of direct interest in this paper, Customer Inertia is referred to as: (i) a consistent pattern of buying the same brand almost every time a consumer shops, out of habit, merely because less effort is required (Solomon, 1994); (ii) repeated patronage of a supplier despite the lack of a positive attitude towards it; (iii) repeated purchases devoid of assessments, featuring unconscious procedures (Huang \& Yu, 1999); (iv) an absence of goal-directed behavior (Zeelenberg \& Pieters, 2004). This rich array represents facets of the same construct as well as different ways it can be explained.

Some authors describe Customer Inertia as a driver for repeated purchases (Yanamandram $\&$ White 2004, 2007; Ranaweera \& Neely 2003) or even for loyalty (Wu, 2011). Let us provide further clarification. Oliver $(1997,1999)$ outlined four phases of customer loyalty. The last one, 'action loyalty', involves 'action inertia', in which repeated purchases become a reflex of habitual action, as a result of strong commitment to repurchasing the brand, combined with a desire to overcome obstacles to carry out the acquisition. That is the concept adopted in this paper, which features repeated patronage without a positive attitude.

According to Bozzo (2002), consumers can be tangled "in an inert pattern in order to reduce their cost of thinking or just because they show limited interest towards the alternative brands on the market" (p. 2), leading to Customer Inertia as an outcome. As an outcome the construct has both attitudinal and behavioral antecedents.

A well-known framework presents three generalized antecedents of attitude: cognitive (information regarding the object), affective (feelings related to the object), and conative (inclinations to act toward the object) (Dick \& Basu, 1994). Applying this framework, we now focus on possible relationships of Customer Inertia to its: (a) cognitive antecedents: Market Isomorphism, Perceived Service Quality, and Unattractiveness of Alternatives; (b) affective antecedent: Satisfaction; and (c) conative antecedents: Switching Barriers and Switching Avoidance.

\subsection{Market Isomorphism}

Market Isomorphism has to do with the homogeneity of providers, meaning that their performed processes and delivered outcomes are almost the same. At the extreme of Isomorphism, everything one company does and offers, its competitors do and offer too. The world has seen a growing similarity among competing organizations in various aspects, such as in products, pricing, and promotion. Many firms strive for competitive advantage through differentiation (i.e., delivering higher levels of valued benefits to one or more segments). These first-rate benefits, however, are often copied (even quickly), a fact that dampens competitiveness (Porter, 1998). A differential edge could be maintained if rooted in unique and difficult to imitate elements (Vasconcelos \& Cyrino, 2000), but this is a huge challenge. Eventually, many firms end up providing similar goods and services in the customers' eyes, forming a homogenized sector. This is Market Isomorphism.

'Isomorphism' - a term from Institutional Theory (Meyer \& Rowan, 1977) - is a process that compels one organization to resemble another, when they compete under the same environmental conditions (Dimaggio \& Powell, 2005). Such 'mimetic isomorphism' requires a permanent battle for a renewed advantageous position. Nowadays, equivalent players are common in countless sectors.

From a broader perspective, Gimenez, Hayashi Junior, and Grave (2007) observed isomorphic strategies, both current and future, in industries from diverse sectors, such as electronics, clothing, metallurgy, and leisure. Rossetto and Rossetto (2005) describe the influence of institutional isomorphism on strategic development for construction firms, indicating mimetic and coercive isomorphisms as being the most important. 
Among the aspects they researched, Zacharias, Figueiredo, and de Almeida (2008) observed similarity in the banking industry, in terms of products and services. Urdan and Zuñiga (2001) verified similar goods manufactured by competing firms, identifying service differentiation as a possible source for competitiveness. Mesquita and Lara (2007) reported similar pricing by supermarkets in a big city, despite the different income levels of their target markets. Pereira Filho, Campos, and Nóbrega (2015) identified great similarity between fast food restaurants in Brazil. They evaluated 45 attributes concerning service quality in 15 restaurants, and out of 675 possible scores, 496 , or $73.5 \%$, were below the average rate customers expected. The physical evidence used by hospitals and hotels is very similar, as shown by Mendonça, Barbosa, and Durão (2007), when studying the Brazilian hospitality industry. Thus, Market Isomorphism makes sense as a concept, as a summarization of many concrete observations and to describe what they have in common.

Bowen (1990) found that customers do not see any striking distinction between service providers from various sectors (e.g., fast-food restaurants and theme parks). In the cell phone business, Mesquita, Martins, and Bastos (2015) identified a positive relationship between: a) isomorphism and inertia; and b) the customer service gap and inertia. If a potential customer is unable to distinguish service (or goods) providers in terms of benefits, the chosen supplier does not matter for him/her. In this case, irrespective of the vendor, the customer thinks that the quality received will be almost the same, which decreases the incentive to switch to another provider. That is the rationale for the following two hypotheses.

H1a - Market Isomorphism is positively related to Unattractiveness of Alternatives.

H1b - Market Isomorphism is positively related to Customer Inertia.

\subsection{Perceived Service Quality}

Perceived Service Quality is the difference between perceptions and expectations. Service perceptions are the customer's judgments regarding the excellence of a service rendered and the expected quality of services to be performed and received (Parasuraman et al, 1988). Those expectations are a combination of the customer's predictions about what is likely to happen during a service transaction and his/her wants and desires (Zeithaml, Berry, \& Parasuraman, 1993). A negative Perceived Service Quality represents a service gap (Zeithaml \& Bitner, 2003). The inflexion point is a zero gap (perceptions equal to expectations). A negative Perceived Service Quality might stimulate the customer to switch the corresponding provider. On the other hand, increased and positive Perceived Service Quality should reinforce the incumbent customer-vendor link. Often, high Perceived Service Quality is not the frequent case around the world, and many consumers are conscious of this scenario (Bitner, Booms, \& Tetreault 1990). Differentiation through service quality is a very attractive proposal. For the customer that is receiving his/ her expected quality, it is natural and rational to stay with the incumbent supplier; it would not make sense to divert attention elsewhere. Summing up, positive Perceived Service Quality should discourage the consumer from switching providers and favors Switching Avoidance. Based on the above, we propose the hypotheses below.

H2a-Perceived Service Quality is positively related to Switching Avoidance.

H2b - Perceived Service Quality is positively related to Customer Inertia.

\subsection{Unattractiveness of Alternatives}

The attractiveness of alternatives: a) "refers to customer perceptions regarding the extent to which viable competing alternatives are available in the marketplace" (Jones, Mothersbaugh, \& Beatty, 2000, p. 263); and b) is based on the 
quality that customers anticipate as obtainable in the best available alternative (Yanamandran \& White, 2007). Some authors (e.g., Jones, Mothersbaugh, \& Beatty, 2000; Wu, 2011) have pointed out the great influence this construct exerts on repeated purchases. Four dimensions characterize the unattractiveness of alternatives: number of available alternatives, difference between alternatives, difficulty to understand the alternatives, and difficulty to compare the alternatives (Wu, 2011).

As the attractiveness of alternatives increases, the customer should be less passive about problems attributed to the incumbent supplier, confronting it, looking out for a substitute, and/or breaking the link between them (Ping Jr., 2001). We imagine that a customer aware of very similar competing service providers tends to poorly detect unfavorable differences between the expected and experienced qualities of his/her current supplier. That is, the customer attenuates or even does not realize a service gap, as he/she already knew that a poor service would be experienced (depressed expectations). Nevertheless, the customer does not bother much about this, as he/she does not expect to get a better offer elsewhere in the sector.

Wu (2011) detected a direct and positive effect of Satisfaction on customer loyalty along with a direct and negative effect of Alternative Attractiveness on the same dependent construct. An opposite construct is 'customer indifference' (Ranaweera \& Neely, 2003) or Unattractiveness of Alternatives (a better name), which is the customer's perception that switching the provider will not lead to a substantially improved offer. Hence, Unattractiveness of Alternatives may stimulate Customer Inertia. In addition, as the consumer envisions that alternative vendors have the same or similar quality, he/she is urged to avoid switching. This is the logic behind the next pair of hypotheses.

H3a - Unattractiveness of Alternatives is positively related to Switching Avoidance.
H3b - Unattractiveness of Alternatives is positively related to Customer Inertia.

\subsection{Switching Barriers}

Switching Barriers are mechanisms, normally engendered or imposed by suppliers, that make customer defection difficult or, in a worst-case mode, actively prevent such defection. This is a commonly adopted tactic aiming to increase loyalty in industrial markets (Dick \& Basu, 1994) or to lock in the customer.

On the customer's side, Switching Barriers corresponds to the perception of the magnitude of the sacrifices required to terminate a relationship and to begin another somewhere else (Yanamandram \& White, 2006). These sacrifices may include time, money, and effort (Jones, Mothersbaugh, \& Beatty, 2000). Switching cost is one of the Switching Barriers, the "onetime costs that consumers associate with the process of switching from one provider to another" (Burnham, Frels, \& Mahajan, 2003, p. 110). Switching Barriers emerge from idiosyncratic investments made by the customer in a vendor. Lee and Neale (2012) investigated Australian customers of mobile phone providers, using Customer Inertia as a moderator. One of their conclusions was that switching costs deter provider substitution when Customer Inertia is low. With high Inertia, retention depends on whether the inertia stemmed from Satisfaction or indifference (i.e., Switching Avoidance). With indifferent customers, switching costs are unrelated to retention. Yet, we think it is more appropriate to take Customer Inertia as a dependent construct. In addition, if Switching Barriers increase for a customer, his/her propensity to stay with the incumbent supplier should rise as well as the inertial posture. This reasoning supports two more hypotheses.

H4a - Switching Barriers are positively related to Switching Avoidance.

H4b - Switching Barriers are positively related Consumer Inertia. 


\subsection{Satisfaction}

Customer Satisfaction is the psychological state inherent to an acquisition and/or a consumption experience, resulting when the emotion of first impressions about the experience is coupled with confirmed/disconfirmed expectations (Oliver, 1981, 2015). Satisfaction is a measure of how a supplier's offer meets or surpasses the overall expectations of the customer, taking into account her/his expectations, the perceived performance, and the difference between these two components (Rossi \& Slongo, 1998). Satisfaction can refer to a particular transaction or to the cumulative transactions of a buyer-seller connection (Garbarino \& Johnson, 1999; Jones, Mothersbaugh, \& Beatty, 2000). In the first case, satisfaction is an evaluation processed immediately post-consumption, while the second case concerns the evaluation of several transactions undertaken with a vendor over a period. This paper focuses on cumulative Satisfaction involving the entire bundle of benefits from a provider.

Satisfaction is a key performance indicator for many organizations, because of its multiple effects (Lütkemeyer Filho, Vaccaro, \& Freitas, 2015; Farias \& Santos, 2000). Its impacts include attitudinal (switching avoidance, brand loyalty) and behavioral (repeated purchases, word of mouth) consumer responses (Gustafsson, Johnson, \& Roos, 2005). Ultimately, Satisfaction influences the seller organization's market share and profitability (Anderson \& Sullivan, 1993). Thus, we devise the following hypotheses.

H5a - Satisfaction is positively related to Switching Avoidance.

H5b - Satisfaction is positively related to Customer Inertia.

\subsection{Switching Avoidance}

Switching suppliers, for many customers in diverse contexts, can mean loss of time and effort that do not necessarily lead to better results. A person in a state of Switching Avoidance does not like changing and/or is too lazy to search for superior alternatives, which causes passive and stable behavior. Apathy also acts as a barrier to switching (Colgate \& Lang, 2001), comprised of the impressions that "all organizations are the same" and it is "too much bother". The apathetic client prefers the status quo. A consumer who exhibits inertia is a variety avoider, characterized by laziness, inactiveness, and/or passiveness (Wu, 2011). He/she refrains from switching suppliers on the grounds that either: i) the change would not totally compensate for the additional efforts; ii) he/she is unwilling to make the effort to establish a new link elsewhere; and iii) he/she dislikes taking risks. For these reasons, we propose the final hypothesis.

\section{H6 - Switching Avoidance is positively related to Customer Inertia.}

The hypotheses above lead to our Base Model of Customer Inertia Antecedents mediated by Switching Avoidance. We also conceive a simpler Rival Model that does not include Switching Avoidance as a mediator. This mediator may be quite similar in nature to Customer Inertia and a similar overlap may occur between Market Isomorphism and Unattractiveness of Alternatives. Thus, the Rival Model consists of only the direct effects of Market Isomorphism, Perceived Service Quality, Unattractiveness of Alternatives, Switching Barriers, Satisfaction, and Switching Avoidance on Customer Inertia. As such, the Rival Model retains only hypotheses $\mathrm{H} 1 \mathrm{~b}, \mathrm{H} 2 \mathrm{~b}$, $\mathrm{H} 3 \mathrm{~b}, \mathrm{H} 4 \mathrm{~b}, \mathrm{H} 5 \mathrm{~b}$, and H6. Figure 1 displays the two conceptual Models; above all, they require empirical testing. Additionally, doubts remain about differences in the relationships with regard to Gender and Income. These doubts also exist with respect to Contract Type for mobile phone services (prepaid versus postpaid). 


\section{Empirical Method, Procedures, and Investigated Sector}

To test the models, a descriptive quantitative study was undertaken. For the survey, subjects were instructed to evaluate, as customers, the mobile telecommunications sector in Brazil. The initial sample (drawn by convenience) consisted of graduate students from a Brazilian university who personally completed the questionnaire. Those subjects were also requested to pass along the questionnaire web link on the Google docs' website to their contacts (thus giving rise to a snowball sampling procedure). The respondents were informed about the research objectives and anonymity was assured.

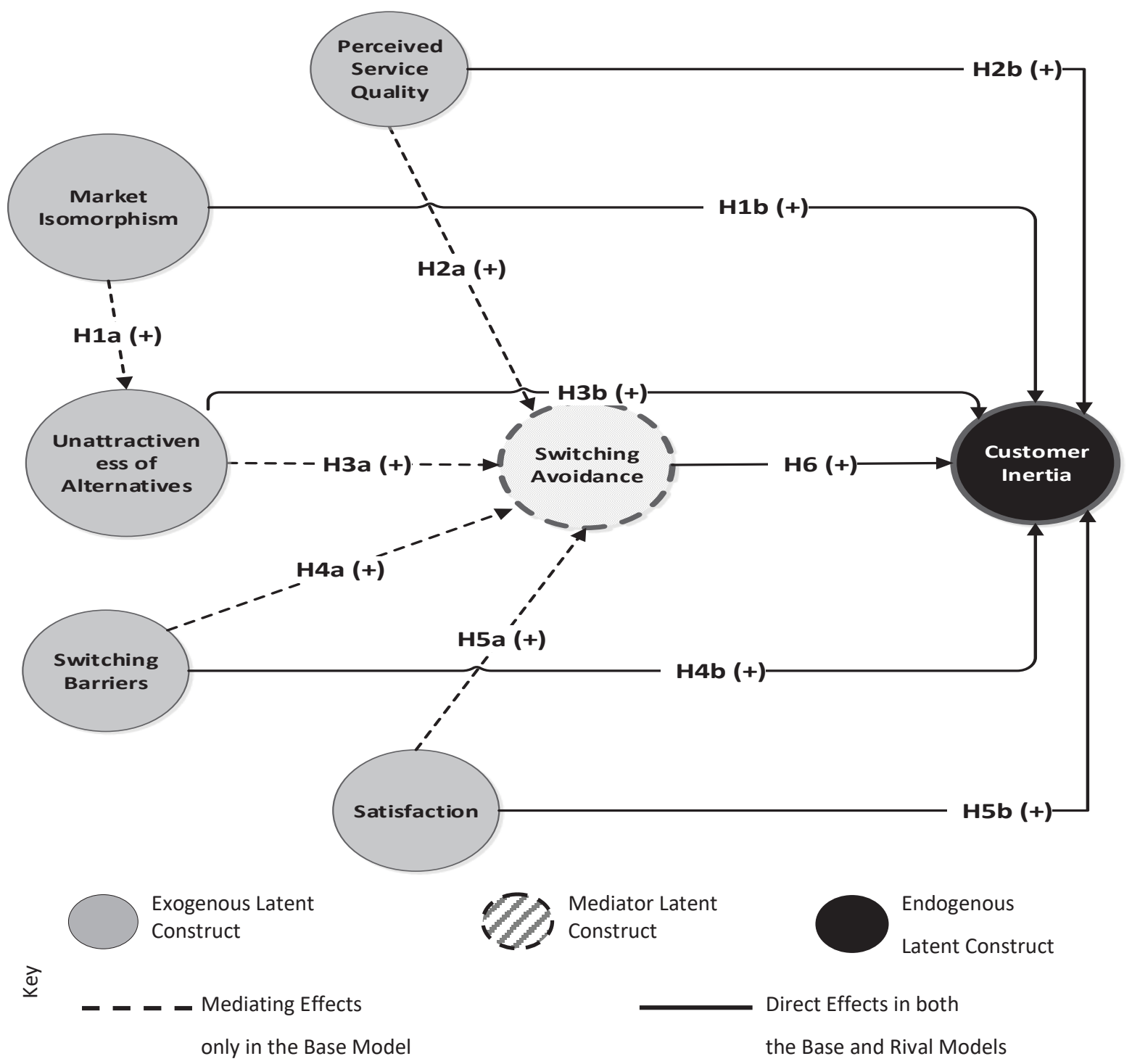

Figure 1. Base and Rival Models

The questionnaire (Appendix) first assesses the service provider used by the subject and some aspects of their relationship, such as operator name, type, and age of the contract, and how frequently the subject switched providers. Then,
Satisfaction is measured on a 4-point interval scale ('very dissatisfied', 'dissatisfied', 'satisfied', 'very satisfied'), thus preventing a neutral positioning. Next, the questionnaire includes scales for: a) Customer Inertia, using indicators from 
Yanamandran and White (2004), Anderson and Srinivasan (2003), and Zeelenberg and Pieters (2004); b) Switching Avoidance, using indicators developed by the authors in accordance with Wu (2011, p. 33); and c) Switching Barriers and Unattractiveness of Alternatives, according to Colgate and Lang (2001) and Ping (2001). All these measurements are on a 7-point interval scale, ranging from 'strongly disagree' to 'strongly agree'.

The operationalization of both Perceived Service Quality and Market Isomorphism (Mesquita, Martins, \& Bastos, 2015) is based on the seven Service Marketing components (Zeithaml \& Bitner, 2003): product, price, place, promotion, people, process, and physical evidence. Their items are on a 7-point interval scale, ranging from: a) ' 1 - very different' to ' 7 - very similar' for Market Isomorphism; and b) ' 1 - poorer than expected' to 'exactly as expected' for Perceived Service Quality. The literature describes the latter construct's spectrum as ranging from 'below the expected' to 'above the expected' quality or 'worse' versus 'better' than expected. However, a previous focus group did not reveal any cases of consumers' endorsing superior perceived quality, not even one of quality equal to that expected. For this reason, we constrained the upper label of the scale to 'exactly as expected'. Finally, the questionnaire measures the respondents' socio-demographic profile (age, income level, marital status, and job). The questionnaire (in Portuguese) can be obtained from the first author.

Structural Equation Modeling was applied using the PLS 3.0 software, including multi-group analyses to test differences in Customer Inertia associated with customer Age, Income Level, and Contract Type.

\section{I Investigated Sector}

The sector examined - mobile telecommunications - has characteristics that are well suited to testing the hypotheses and models: ongoing service, small number of providers, frequent customer complaints, and low turnover rate. Table 1 shows a (incomplete) time series of the market share for Brazilian mobile telecommunications operators. The stability maintained by each player (especially Vivo, Tim, and Claro) over 11 years (from 2007 to 2017) is noticeable. These providers also have high customer complaint rates (Veja, 2015). In 2014, customer complaints regarding mobile phone operators at a public consumer protection agency (Procon) -accounted for $9.5 \%$ of the grand total number of filed complaints (related to all suppliers from all sectors). Even so, mobile phone firms in the country had relatively low turnover rates, at about $3.7 \%$ in 2015 (Teleco, 2017).

Table 1

\section{Evolution of market share for mobile phone operators in Brazil (2013-2016)}

\begin{tabular}{|c|c|c|c|c|c|c|}
\hline Operator & 2007 & 2013 & 2014 & 2015 & 2016 & 2017 \\
\hline Vivo & $29.84 \%$ & $28.49 \%$ & $28.47 \%$ & $28.42 \%$ & $30.23 \%$ & $31.69 \%$ \\
\hline Tim & $25.85 \%$ & $27.09 \%$ & $26.97 \%$ & $25.69 \%$ & $25.98 \%$ & $24.79 \%$ \\
\hline Claro & $24.99 \%$ & $25.34 \%$ & $25.33 \%$ & $25.59 \%$ & $24.65 \%$ & $24.96 \%$ \\
\hline Oi & $13.21 \%$ & $18.52 \%$ & $18.14 \%$ & $18.64 \%$ & $17.27 \%$ & $16.47 \%$ \\
\hline Density & $63.59 \%$ & $134.4 \%$ & $138.0 \%$ & $139.2 \%$ & $118.4 \%$ & $113.5 \%$ \\
\hline
\end{tabular}

Note. Source: Teleco (2018). Density: percentage of active mobile accesses (lines) relative to the population.

The mobile telephone services in Brazil comprise three contract types: a) prepaid (no minimum fee but previous payment is required); b) postpaid (minimum monthly subscription fee, post and monthly payment), and contract (business plan). In the country the total number of lines shrank by $5.33 \%$ in 2016 (13.7 million fewer lines), to 244 million lines (Brigatto, 2017). In terms of contract type, prepaid lines shrank by $10.75 \%$, to 165 million lines and, in the opposite 
direction, postpaid lines grew by $8.32 \%$, to 79.3 million.

\section{Findings}

The final sample has 249 respondents (185 from electronic interviewing, 64 from personal contact). This sample size is enough, as the minimum size necessary for a statistical power of $80 \%$ would be 217 , considering 6 exogenous variables (Hair et al., 2014, 21). ANOVAs did not indicate differences between these two subsamples in the measured variables (indicators) pertaining to the seven constructs in the Conceptual Models. As to 'service provider' in the final sample, the distribution includes 37.3\% VIVO, 28.9\% TIM, $17.3 \%$ OI, $12.4 \%$ CLARO, and $4.1 \%$ other operators. Regarding 'contract type', 51\% are 'prepaid' consumers, $39.8 \%$ are 'post-paid', and $9.2 \%$ are 'business'. The respondents' average 'number of providers experienced' is 2.5 and the average 'time with the current provider' is 6.6 years (a relatively long time, in itself suggesting a high retention rate).

A preliminary data analysis showed non-normality in the variables pertaining to the Conceptual Models, indicating the use of PLS (Hair et al. 2014). No outlier was found. The few missing data (all in personal interviews) were replaced with the mean value. The measurement model consisted of 44 measured variables and 7 latent variables (constructs). In the measurement models at the latent variable level, all the Cronbach's Alphas are above 0.7 and all the Composite Reliabilities are above 0.8 (Hair et al, 2014); so random error is not a problem in those scales. In the Average Variance Extracted (AVE), Market Isomorphism (0.463) and Switching Barriers (0.461) represent the lowest scores, although even these were near the lower limit 0.5 (Chin, 1988; Hair et al, 2014) or within the 0.4 lower limit for exploratory studies (Nunnaly $\&$ Bernstein, 1994). Based on the Fornell-Larcker criteria (Chin, 1988; Hair et al, 2014), there are discriminant validities among the constructs, as the square root of the Average Variance Extracted (AVE) for each construct is always higher than the bivariate correlations between that construct and each of the other constructs.

The two structural models' results are in Table 2. Further down, Figures 2 and 3 portray the estimated structural parameters for the Base and Rival Models, respectively. The significance level of indicator loadings and path coefficients were tested using the bootstrapping procedure.

\section{I Direct Effects}

Regarding the direct effects on Customer Inertia, only the antecedent Unattractiveness of Alternatives $(\mathbf{H} 3 \mathbf{b})$ is not significant in both models ( $\lambda=0.077$ in the Base Model; $\lambda=0.116$ in the Rival Model). The path between Switching Barriers and Customer Inertia (H4b) is confirmed only in the Rival Model $(\lambda=0.191, \mathrm{p}<0.01)$.

The path from Market Isomorphism to Customer Inertia (H1b), although significant, is negative in the Base $(\lambda=-0.177, \mathrm{p}<0.05)$ and Rival $(\lambda=-0.224, \mathrm{p}<0.05)$ Models. This inverse relationship was not expected (Mesquita, Martins, $\&$ Bastos, 2015). It may be that as clients become bored in the case of Market Isomorphism they search more for new providers, even without expecting to find others that are different and better than the current one. Such switching could be a kind of warning or punishment to the incumbent company, despite no improvement gained by the customer in the new patronage. 
Table 2

Structural models' results (Base and Rival)

\begin{tabular}{|c|c|c|c|c|c|}
\hline \multirow{2}{*}{$\begin{array}{l}\text { Dependent variable: } \\
\text { inertia }\end{array}$} & \multicolumn{2}{|c|}{ Base Model } & \multicolumn{2}{|c|}{ Rival Model } & \multirow{2}{*}{ Hypotheses } \\
\hline & Path Coefficient & $\mathbf{f}^{2}$ & Path Coefficient & $\mathbf{f}^{2}$ & \\
\hline ISO & $-.177^{* *}$ & .028 & $-.224^{* *}$ & .062 & $\mathrm{H} 1 \mathrm{~b}$ \\
\hline PSQ & $.295^{*}$ & .111 & $.263^{*}$ & .098 & $\mathrm{H} 2 \mathrm{~b}$ \\
\hline UNA & $.077^{\mathrm{ns}}$ & .005 & $.116^{\mathrm{ns}}$ & .015 & $\mathrm{H} 3 \mathrm{~b}$ \\
\hline SBA & $.098^{\mathrm{ns}}$ & .011 & $.191^{*}$ & .048 & $\mathrm{H} 4 \mathrm{~b}$ \\
\hline SAT & $.263^{*}$ & .085 & $.233^{*}$ & .073 & $\mathrm{H} 5 \mathrm{~b}$ \\
\hline SAV & $.242^{*}$ & .065 & $.243^{*}$ & .076 & H6 \\
\hline Switching Avoidance & $\overline{\mathbf{R}}^{2}: \mathbf{0 . 2 8 6}$ & $Q^{2}: \mathbf{0 . 1 4 7}$ & $\overline{\mathbf{R}}^{2}: 0.354$ & Q2: 0.181 & \\
\hline PSQ & $.051^{\mathrm{ns}}$ & .003 & --- & --- & $\mathrm{H} 2 \mathrm{a}$ \\
\hline UNA & $.241^{*}$ & .067 & --- & --- & $\mathrm{H} 3 \mathrm{a}$ \\
\hline SBA & $.354^{*}$ & .150 & --- & --- & $\mathrm{H} 4 \mathrm{a}$ \\
\hline SAT & $.022^{\mathrm{ns}}$ & .001 & --- & --- & $\mathrm{H} 5 \mathrm{a}$ \\
\hline $\begin{array}{l}\text { Unattractiveness of } \\
\text { Alternatives }\end{array}$ & $\overline{\mathbf{R}}^{2}: .210$ & Q2:.105 & --- & & \\
\hline \multirow[t]{2}{*}{ ISO } & $.607^{*}$ & .584 & --- & -- & $\mathrm{H} 1 \mathrm{a}$ \\
\hline & $\overline{\mathbf{R}}^{2}: .369$ & Q2:.190 & --- & & \\
\hline
\end{tabular}

Note. Significance: ${ }^{*} 1 \%(\mathrm{t}>2.58) ;{ }^{* *} 5 \%(\mathrm{t}>1.96) ;{ }^{\text {ns }}$ non-significant.

$\mathrm{f}^{2}$ calculated by the following formula (Hair et al, 2014): $f^{2}=\frac{R_{\text {included }}^{2}-R_{\text {excluded }}^{2}}{1-R_{\text {included }}^{2}}$

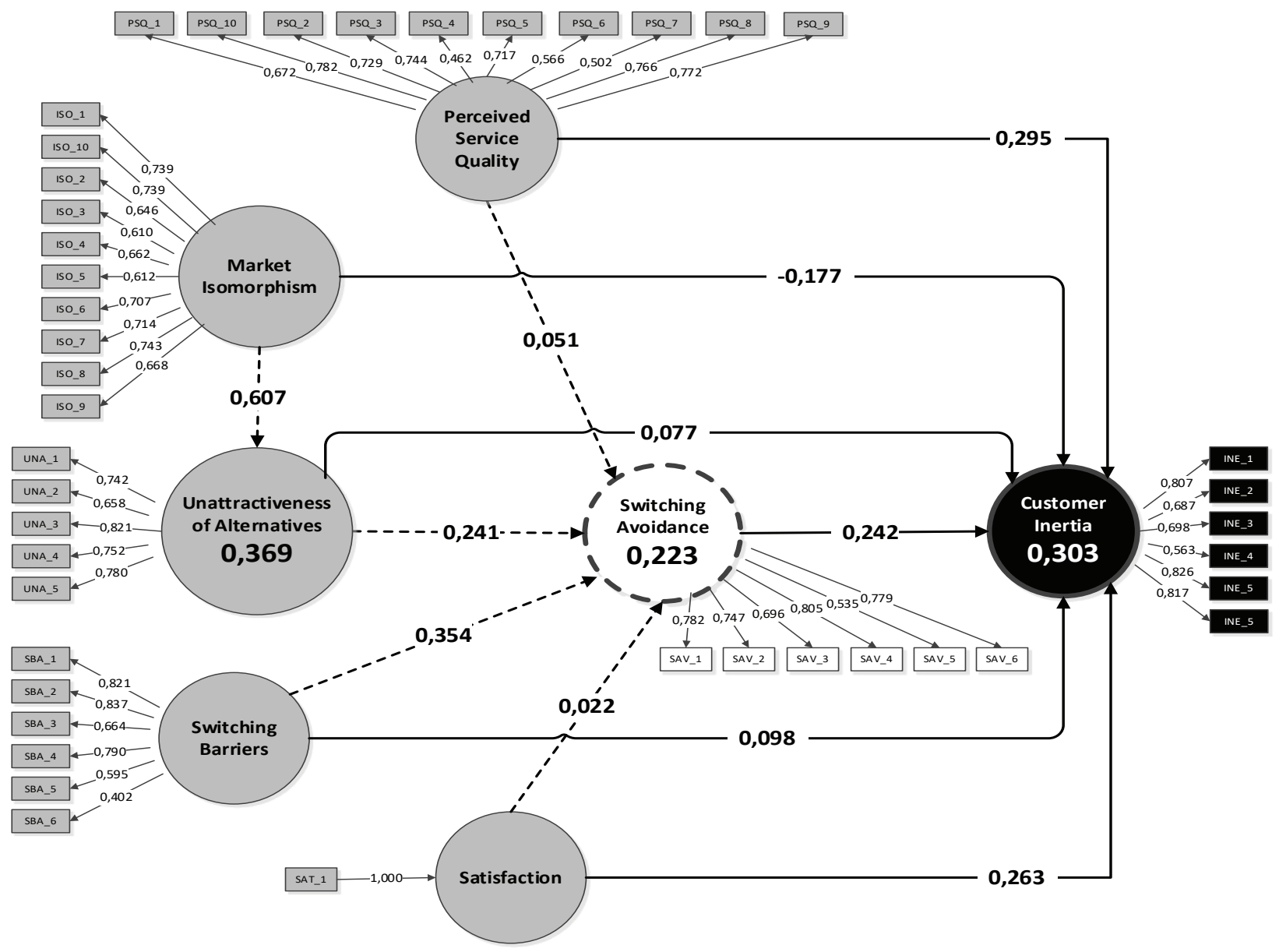

Figure 2. Base Model. 
The positive tie between Perceived Service Quality and Customer Inertia (H2b) was supported in both Models (Base, $\lambda=0.295$, $\mathrm{p}<0.01$; Rival, 0.263, $\mathrm{p}<0.01)$. This makes sense: the more the superiority of an experienced service compared to the expectation, the more consumer inertia, in terms of supplier, would occur. In addition, favoring the uncompetitive vendors, perceived quality can be positive even after an inferior experience, as long as the expectation is relatively worse, which is a common occurrence in the sector (Market Isomorphism), thus preventing any gap. Any service level received tends to be considered with respect to the expected level. Above all - as posited by Zeithaml, Berry, and Parasuraman (1993) and Zeithaml and Bitner (2003) - if a customer receives service quality, he/ she tends to stay with the seller already in use.

The relationship between Switching Barriers and Customer Inertia (H4b) was confirmed in the Rival Model $(\lambda=0.191, \mathrm{p}<0.01)$. Barriers involve the consumer's perceptions of the time, money, and effort required to change provider (Yanamandram \& White, 2006; Jones, Mothersbaugh, \& Beatty, 2000). So, when faced with expressive (inexpressive) costs to move to another company, inertia should be reinforced (weakened). These costs act to convince him/her to avoid changing.

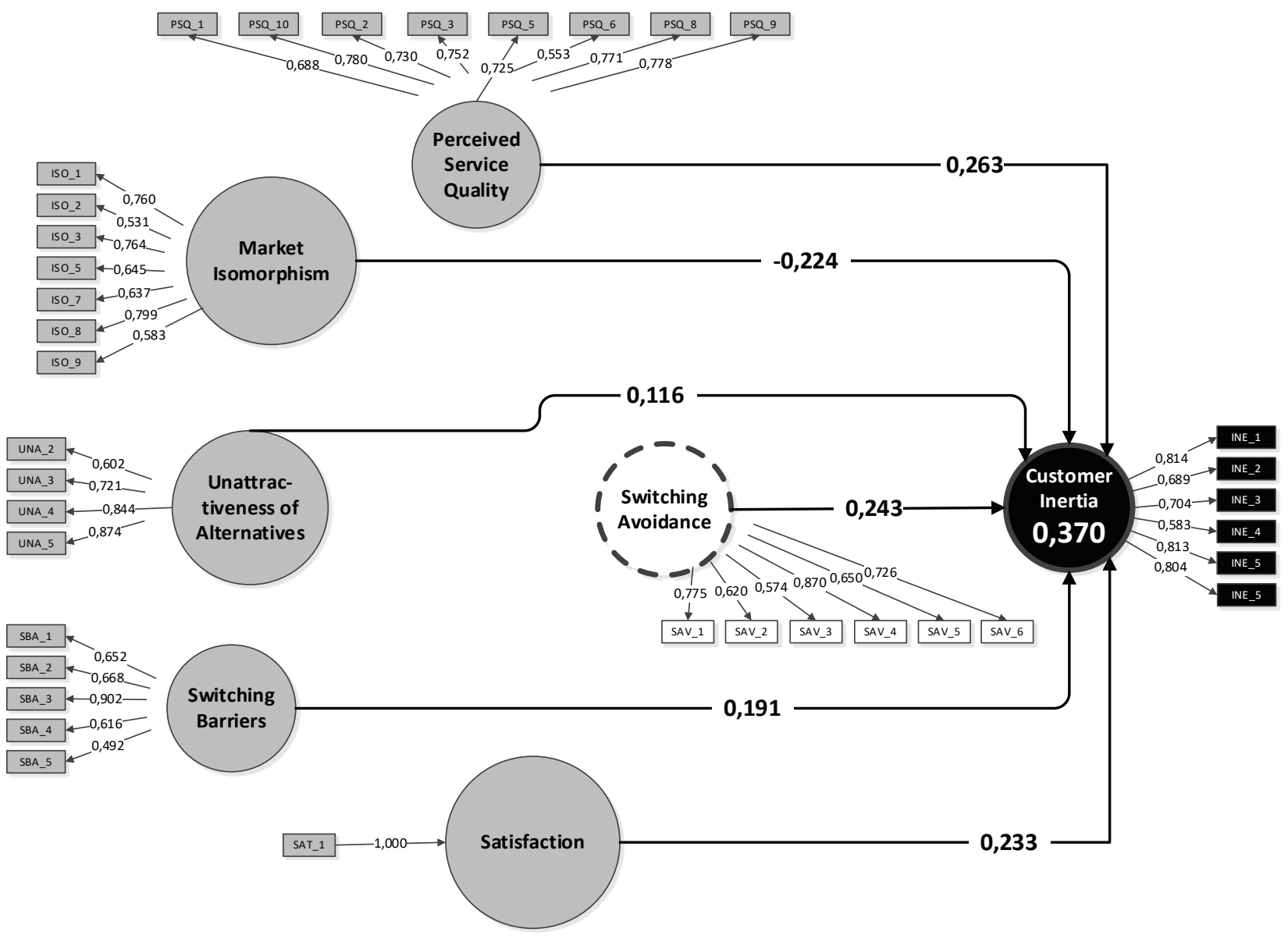

Figure 3. Rival Model

A significant link between Satisfaction and Customer Inertia (H5b) appeared for the Base $(\lambda=0.263, \mathrm{p}<0.01)$ and Rival $(\lambda=0.233$, $\mathrm{p}<0.01)$ Models. Satisfaction is a relevant driver for repeated purchases and even attitudinal loyalty (Farias \& Santos, 2000; Zeithaml, Berry, \& 
Parasuraman, 1993; Zeithaml \& Bitner, 2003). Under such a state, the customer should refrain from pursuing solutions (through services and/ or goods) elsewhere; i.e., adopting an inertial posture. Continuous patronage is a component of inertial behavior. This result is in line with: a) Jones, Mothersbaugh, and Beatty (2000), who found a positive influence of satisfaction on repeated purchases; b) Anderson and Srinivasan (2003), who describe the link between satisfaction and e-loyalty; and c) Bozzo (2002), who identified high levels of satisfaction for inert customers. However, Ping Jr. (2001) did not confirm the importance of satisfaction in determining loyalty.

The link between Switching Avoidance and Customer Inertia (H6) was confirmed in both the Base $(\lambda=0.242, \mathrm{p}<0.05)$ and the Rival $(\lambda=0.243, \mathrm{p}<0.05)$ models. This outcome reflects the case of people who do not like changes and end up staying with the same vendor organization (Colgate \& Lang, 2001). This implies a phenomenon in which an increase (decrease) in a personal state (Switching Avoidance) leads to immobilization (mobilization) towards substitutes in the market arena.

\subsection{Mediating and Indirect Effects}

Of the four mediating effects hypothesized for Switching Avoidance (dotted lines in Figures 1 and 2), two were underpinned (H3a and H4a): the antecedents Unattractiveness of Alternatives and Switching Barriers. The links between both Perceived Service Quality (H2a) and Satisfaction (H5a) with Switching Avoidance were refuted.
In the case of Satisfaction (H5a), the result was surprising, as a satisfied customer has many incentives to stay with the same provider. The confirmed connection between Unattractiveness of Alternatives (H3a) and Switching Avoidance $(\lambda=0.241, \mathrm{p}<0.01)$ means that the worse other providers are perceived to be by the client, the stronger his/her state of unwillingness for transition, and vice-versa. The effect of Switching Barriers on Switching Avoidance (H4a) $(\lambda=0.354$, $\mathrm{p}<0.01)$ was supported. This highlights that company techniques and sector characteristics that increase the total costs (time, money, and psychological) for customer migration encourage them to avoid such change. The impact of Market Isomorphism on Unattractiveness of Alternatives (H1a) was supported $(\lambda=0.607, \mathrm{p}<0.01)$. These are similar constructs, but not identical. The former refers to the attributes of competing suppliers in a sector, and the latter means the outcomes they deliver [including Gronroos' (1994) functional quality (process) and technical quality (outcome) in service provision]. For the customers in the sample, an interesting scenario does not ensue from an array of homogenous players.

Regarding the indirect effects on Customer Inertia, shown in Table 3, none of them (ranging from no more than 0.012 to 0.085 ) were significant, which rejects the mediating role of Switching Avoidance. Alternatively, Market Isomorphism has only a light indirect effect (0.146) on Switching Avoidance.

Table 3

\section{Indirect Effects}

\begin{tabular}{lccccc}
\hline & \multicolumn{4}{c}{ Relationship } \\
\cline { 2 - 6 } & ISO $\rightarrow$ INE & PSQ $\rightarrow$ INE & UNA $\rightarrow$ INE & SBA $\rightarrow$ INE & ISO $\rightarrow$ SAV \\
\hline Indirect Effect & $.082^{\text {ns }}$ & $.012^{\text {ns }}$ & $.058^{\text {ns }}$ & $.085^{\text {ns }}$ & $.146^{* *}$ \\
\hline
\end{tabular}

Note. ${ }^{* *}$ Significant at $95 \%(\mathrm{t}>1.96)^{\mathrm{ns}}$ non-significant. 
Summing up, the Rival Model is simpler, has a higher explanatory power for Customer Inertia $\left(\overline{\mathrm{R}}^{2}\right.$ of 0.35 compared to 0.29 for the Base Model), has a higher effect size $\left(f^{2}\right)$ for four of the six relationships tested, higher predictive relevance $\left(\mathrm{Q}^{2}\right.$ of 0.181 compared to 0.147$)$, and confirms five out of six of the hypotheses. Additionally, the hypothesized mediating role of Switching Avoidance in the Base Model - amidst the exogenous constructs and Customer Inertia
- was rejected. As such, the Rival Model is more advantageous as a conceptual framework; it is now adopted here.

\subsection{Multi-group Analyses}

Table 4 reports multi-group analyses, of the variables Gender, Income, and Contract Type, for the Rival Model (Figure 3), which connects each exogenous construct to Customer Inertia.

Table 4

\section{Group Analysis.}

\begin{tabular}{|c|c|c|c|c|c|c|}
\hline \multirow{3}{*}{$\begin{array}{l}\text { Dependent } \\
\text { variable: inertia }\end{array}$} & \multicolumn{2}{|c|}{ Gender } & \multicolumn{2}{|c|}{ Income* } & \multicolumn{2}{|c|}{ Contract Type } \\
\hline & Male & Female & Low & High & Postpaid & Prepaid \\
\hline & \multicolumn{6}{|c|}{ Path coefficient } \\
\hline PSQ & .380 & .168 & .210 & .277 & .263 & .281 \\
\hline ISO & -.142 & -.332 & -.161 & -.230 & -.088 & -.266 \\
\hline UNA & .109 & .116 & .074 & .030 & .016 & .220 \\
\hline SAT & .161 & .319 & .245 & .214 & -.016 & .404 \\
\hline SBA & .249 & .169 & .208 & .205 & .302 & .107 \\
\hline SAV & .278 & .215 & .291 & .231 & .333 & .158 \\
\hline$\overline{\mathbf{R}}^{2}$ & .448 & .375 & .361 & .371 & .333 & .473 \\
\hline
\end{tabular}

Note. ${ }^{*}$ Low Income: < US $\$ 30,000 /$ year; High Income: $\geq$ US $\$ 30,000 /$ year.

Regarding Gender, the differences in Perceived Service Quality and Satisfaction stand out. Males are more impacted by Quality with regard to Customer Inertia $(\lambda=0.380)$ than females $(\lambda=0.168)$. On the contrary, Customer Inertia is more impacted by Satisfaction among the females $(\lambda=0.319)$ than among the males $(\lambda=0.161)$. Family Income was operationalized with two groups: low ( $<$ US\$30,000 per year) and high ( $\geq$ US\$ 30,000 per year). These categories are quite similar in terms of the explanatory power for Customer Inertia in the set of exogenous constructs (Low Income $\overline{\mathrm{R}}^{2}=0.361$; High Income $\overline{\mathrm{R}}^{2}=0.371$ ), but the importance of each exogenous variable is quite different in each group. Switching Avoidance $(\lambda=0.291)$ and Satisfaction $(\lambda=0.245)$ are more robustly connected to Customer Inertia for those with a lower Income, whereas Perceived Service Quality $(\lambda=0.277)$, Switching Avoidance $(\lambda=0.231)$, and Market Isomorphism $(\lambda=-0.230)$ presented a greater influence for those with a high Income. Contract Type includes the categories Postpaid and Prepaid. Of the three multi-group variables, Contract Type exhibits the highest inter group difference in relation to the explanatory power for Customer Inertia (Postpaid $\overline{\mathrm{R}}^{2}=33.3 \%$; Prepaid $\left.\overline{\mathrm{R}}^{2}=47.3 \%\right)$. This explanation for Prepaid is mainly provided by Satisfaction $(\lambda=0.404)$, Perceived Service Quality $(\lambda=0.281)$, and Market Isomorphism $(\lambda=-0.266)$.

\section{Final Remarks}

The objective here was to evaluate antecedents of Customer Inertia and a possible mediating role played by Switching Avoidance. It is a topic that is not yet fully understood that involves an intriguing phenomenon and has some managerial as well as socially relevant 
implications. Customer Inertia - addressed in terms of its attitudinal and behavioral elements - leads to a special type of repeated purchase, without affective attachment to the provider. A conceptual Base Model was built (Figure 1), comprising determinants of Customer Inertia and the mediating effects of Unattractiveness of Alternatives and Switching Avoidance. A Rival Model, without these mediating effects, was also conceived. Then both models were empirically and comparatively tested (Figures 2 and 3).

The Rival Model outperformed the Base Model on a set of criteria (e.g., greater explanatory power for Customer Inertia and more simplicity). The Rival Model offers a moderate explanation $\left(\overline{\mathrm{R}}^{2}=0.35\right)$, some sound structural path coefficients, and appropriate psychometric properties for the latent constructs. For the Rival Model, five out of six hypotheses - referring to antecedents of Customer Inertia - were supported (Table 2). Only Unattractiveness of Alternatives was rejected as having a significant effect. Market Isomorphism had an unexpected negative effect. Maybe an increase in Isomorphism reduces Customer Inertia through resentment, leading the customer to contemplate moving to a competitor even if he/she knows that the incumbent and other providers are similar organizations. The customer might think that he/she must strive for a better vendor, although the rational estimates indicate that they are equivalent; this can be interpreted as a moral duty, irrespective of instrumental results (at least in the short term).

The academic contribution of this paper centers on integrative modeling and empirical testing of many determinants of Customer Inertia, using various scales (multi-items ones, except that for Satisfaction). Market Isomorphism is a new concept, which includes some service attributes. It is different from Attractiveness of Alternatives, as the former relates to service process whilst the latter concerns service outcome. Furthermore, though Customer Inertia has been investigated as a driver of repeated purchases, we believe that a better approach was adopted here, conceptualizing it as a special kind of repeated purchase in the absence of a positive affect for the supplier.

The four confirmed antecedents of Customer Inertia should be carefully considered and possibly managed by: a) business providers striving for better results and competitive advantage; and b) public agencies and nongovernmental organizations (NGO), on behalf of consumer interests. On one hand, as a company works harder to increase its customers' Satisfaction and Perceived Quality, ensuing Customer Inertia would be a valuable result. If these improvements are continued, after a certain point, the clientele could devote more than mere Inertia to the vendor, giving rise to much-aspired brand loyalty. On the other hand, consumer rights protection could require - within some sectors - stricter regulation/legislation in respect to Switching Barriers. If companies, as a whole, consistently neglect Quality and Satisfaction, regulators should be stricter in protecting the consumer, notably in developing countries, as is the case in Brazil. Consumer rights are especially challenging in a market supplied by few competitors, like the one addressed in this research.

In terms of Contract Type, in 2016 mobile phone operators in Brazil registered (Brigatto, 2017) a high turnover for Prepaid lines and an increase in Postpaid clientele. This urges actions specially designed to boost Perceived Service Quality and Satisfaction for Prepaid contracts, which typically involve lower levels for these key marketing indicators. Such an initiative should be worthwhile regardless of the greater revenue derived from Postpaid subscribers. Moreover, a reduction in the inequality of Satisfaction and Perceived Quality between the two contract types would function very well from the perspective of society and the government. Remember that the number of filed customer complaints against operators is at a peak (unfavorable) position in the Brazilian rankings.

Other managerial guidelines arise from the differential effects - depending on the customer Income - of the antecedents on Customer Inertia 
(Table 4). For those with a high income, the impact of Perceived Service Quality is strongest, followed by Switching Avoidance and Market Isomorphism. In the case of those with a low income, the main influence comes from Switching Avoidance, followed by Satisfaction. For both groups, Perceived Service Quality and Satisfaction are relevant in driving inertia, although Switching Avoidance and Barriers also have a great influence. A segmented marketing strategy should be aligned with (or at least take into account) these variables, as most of them (PSQ, SAT, SB) represent variables that are manageable by the companies.

Essentially, the Rival Model results indicate two different avenues that company executives can track to maintain Customer Inertia and its advantages, avenues that are not necessarily mutually exclusive. One front is rooted in Perceived Service Quality and Satisfaction, which are at the center of the marketing orientation. However, it seems that Brazilian mobile phone operators are failing in developing new services and processes able to deliver better Quality and more Satisfaction according to the clientele's expectations, needs, and wants. Even worse, some vendors may be neglecting service, as they know consumers will surely remain with them. Nevertheless, there are limits to Customer Inertia and if Quality and Satisfaction are too low, that can weaken and ultimately break the inertial posture. Another front is based on Switching Barriers and Switching Avoidance, which are both less sustainable and controllable by the provider alone and subject to counter-barriers created by public regulation.

Nonetheless, managers should be aware that, despite its characteristics, Customer Inertia (like human inertia in general) can be broken, leading to change; it is a state, not a personal characteristic (or at least more of a state than a characteristic). In fact, consumers are gaining more awareness about their rights in the market and their resources to react against suppliers' mistakes and inefficacy. Their reactions range from individual departure from one supplier (instead of inertial behavior) to powerful collective weapons, such as social boycotts, an alternative nowadays amplified by virtual social networks (Cruz, 2017). At least in the long run, marketing orientation and business ethics tend to be critical when dealing with customers to achieve sustainable superior business performance (Fernández \& Pinuer, 2016).

We now point out the main research limitations. Market Isomorphism is a relatively new construct that shares some similarities with Unattractiveness of Alternatives. These constructs require more investigation regarding: a) their conceptual and operational definitions; and b) their discriminant validity. The unexpected inverse path from Marketing Isomorphism to Customer Inertia requires further investigation. Anyway, similarly to Charles Darwin's evolutionary view, Science continually produces - and has to produce - new ideas and concepts, although their refinement and even survival depend on environmental factors and requires time (Hull, 1988). New models should deal with the consequences of Customer Inertia, such as peer contagion and provider profitability. In addition, the hard and long road towards scientific generalization of the delineated conclusions requires testing the models on diverse consumer samples and in various sectors. We hope our initiative fosters more research projects focused on Customer Inertia that are able to overcome our limitations and shed light on this thoughtprovoking domain.

\section{References}

Alós-Ferrer, C., Hügelschäfer, S. \& Li, Jiahui. (2016). Inertia and decision making. Frontiers in Psychology, 7(24), 1-9, Feb.

Anderson, E. W. \& Sullivan, M. W. (1993). The Antecedents and Consequences of Customer Satisfaction for Firms. Marketing Science, 12(2), p. $125-143$.

Anderson, E. W. \& Srinivasan, S. (2003). E-Satisfaction and E-Loyalty: a contingency 
framework. Psychology and Marketing, 20(2), 123-138.

Barreto, I.F.; Crescitelli, E. \& Figueiredo, J.C.B. (2015). Relationship Marketing results: proposition of a cognitive mapping model. Revista Brasileira de Gestão de Negócios, 17(58), 1371-1389.

Bitner, M. J., Booms, B. H., \& Tetreault, M. S. (1990). The service encounter: diagnosing favorable and unfavorable incidents. The Journal of Marketing, 71-84.

Bozzo, C. (2002) Understanding inertia in an industrial context. Journal of Customer Behaviour, 1(3), 335-355.

Bowen, J. (1990). Development of a taxonomy of services to gain strategic marketing insights. Journal of the Academy of Marketing Science, 18(1), 43-49.

Brigatto, G. (2017). Brasil perde 13,7 milhōes de linhas de celulares em 2016, diz Anatel. Valor Econômico, Jan 19th.

Chin, W. W. (1998). The partial least squares approach to structural equation modeling. Modern methods for business research, 295(2), 295-336.

Colgate, M., \& Lang, B. (2001) Switching barriers in customer markets: An investigation of the financial services industry. Journal of Customer Marketing, 18(4), 332-347.

Cruz, B.P.A. Social boycott. (2017). Revista Brasileira de Gestão de Negócios, 19 (63), 5-29.

D'Alessandro, S.; Johnson, L.; Gray, D.M. \& Carter, L. (2017). Inertia in services: causes and consequences for switching. Journal of Services Marketing, 31(6), 485-498.

Dick, A., \& Basu, K. (1994). Customer loyalty: toward an integrated conceptual framework. Journal of the Academy of Marketing Science, 22(2), 99-114.
DiMaggio, P. and Powell, W. W. A. (1983) The Iron Cage Revisited: Institutional Isomorphism and Collectivity Rationality in Organizational Field. American Sociological Review, 48(2), 147160.

Farias, S. A., \& Santos, R. C. (2000). Modelagem de equaçóes estruturais e satisfação do consumidor: uma investigação teórica e prática. Revista de Administração Contemporânea, 4(3), 107-132.

Fernández, L.M.V. \& Pinuer, F.J.V. (2016). Influence of customer value orientation, brand value, and business ethics level on organizational performance. Revista Brasileira de Gestão de Negócios, 18 (59), 5-23.

Garbarino, E., \& Johnson, M. S. (1999). The Different Roles of Satisfaction, Trust and Commitment in Customer Relationships. Journal of Marketing, 63(2), 70-87.

Gimenez, F. A. P., Hayashi Júnior, P., \& Grave, P. S. (2007). Isomorfismo mimético em estratégia: uma ferramenta para investigação. RAM. Revista de Administração Mackenzie, 8(4). Groonroos. C. (2004) Marketing: gerenciamento e serviços. Rio de Janeiro: Campus.

Gustafsson, A, Johnson, M. D. \& Roos, I. (2005). The Effects of Customer Satisfaction, Relationship Commitment Dimensions, and Triggers on Customer Retention. Journal of Marketing, 69(4), p.210-218, Oct.

Hair Jr, J. F., Hult, G. T. M., Ringle, C. M., \& Sarstedt, M. (2014). A Primer on Partial Least Squares Structural Equation Modeling (PLS-SEM). Los Angeles, Sage.

Huang, M.H., \& Yu, S. (1999). Are Customers Inherently or Situationally Brand-loyal? A set intercorrelation account for conscious brand loyalty and non-conscious inertia. Psychology and Marketing, 16(6), 523-544.

Hull, D.L. (1988). Science as a Process: An Evolutionary Account of the Social and Conceptual 
Development of Science. Chicago: University of Chicago Press.

Jones, M. A., Mothersbaugh, D. L., \& Beatty, S. E. (2000). Switching Barriers and Repurchase Intentions in Services. Journal of Retailing, 76(2), 259-274.

Khedhaouria, A.; Thurik, R.; Gurau, C., \& van Heck, E. (2016). Customers' Continuance Intention Regarding Mobile Service Providers: A Status Quo Bias Perspective. Journal of Global Information Management, 24(4), p.1-21

Lee, R.; Neale, L. (2012). Interactions and consequences of inertia and switching costs. The Journal of Services Marketing, 26(5), 365-374.

Li-Wei, W. (2011). Satisfaction, Inertia, and Customer Loyalty in the Varying Levels of the Zone of Tolerance and Alternative Attractiveness. The Journal of Services Marketing, 25(5), 310-322.

Lütkemeyer Filho, M.G.; Vaccaro, G.L.R. \& Freitas, E.C. (2015). Identification of Customer Satisfaction in Services: a study on agribusiness dealers. Revista Brasileira de Gestão de Negócios, 17(58), 1408-1425.

Mendonça, J. R. C., Barbosa, M. D. L. D. A., \& Durão, A. F. (2007). Fotografias como um recurso de pesquisa em marketing: o uso de métodos visuais no estudo de organizaçóes de serviços. Revista de Administração Contemporânea, 11(3), 57-81.

Mesquita, J. M. C., Martins, H. M., \& Bastos, A. M. (2015). Inércia do Cliente: Estudo no Setor de Telefonia Móvel. REUNA, 20(2) 139-160.

Mesquita, J. M. C., \& Lara, J. E. (2007). O Preço como Fator de Diferenciação: análise do setor supermercadista. Revista USP, 42(1), 42-51.

Morgan, R. M., \& Hunt, S. D. (1994). The Commitment-Trust Theory of Relationship Marketing. Journal of Marketing, 58(3), 20-38.

Nunnaly, J., Bernstein, I. H. (1994). Psychometric Theory. New York, McGraw-Hill.
Oliver, R. L. (1981). Measurement and Evaluation of Satisfaction Process in Retail Settings. Journal of Retailing, 57(3), 25-48.

Oliver, R. L. (1999). Whence Consumer Loyalty. Journal of Marketing, 63 (special), 33-44.

Oliver R. L. (2015). Satisfaction: a behavioural perspective on the consumer. $2^{\text {nd }}$ ed. London, Routledge.

Pereira Filho, E., Campos, D. F., \& Nóbrega, K. C. (2015). A qualidade de serviços no Fast Food: um estudo das lacunas de percepção em um ambiente de shopping center. HOLOS, 1.

Ping Jr, R. A. (1993) The Effects of Satisfaction and Structural Constraints on Retailer Exiting, Voice, Loyalty, Opportunism, and Neglect. Journal of Retailing, 69(3), 320-352.

Parasuraman, A.; Zeithmal, V. A. \& Berry, L. L. (1988). SERVQUAL: a multiple-item scale for measuring customer perceptions of service quality. Journal of Retailing, 64(1), p. 12-40,

Porter, M. E. (1998). Competitive Strategy: techniques for analyzing industries and competitors. New York, Free Press.

Ranaweera, C. \& Neely, A. (2003). Some Moderating Effects on the Service QualityCustomer Retention Link. International Journal of Operations and Production Management, 23(2), 230-248.

Rossetto, C. R., \& Rossetto, A. M. (2005). Teoria Institucional e Dependência de Recursos na Adaptação Organizacional: uma visão complementar. RAE-eletrônica, 4(1), 1-22.

Rossi, C. A. V., \& Slongo, L. A. (1998). Pesquisa de Satisfação de Clientes: o Estado-da-Arte e Proposição de um Método Brasileiro. Revista de Administração Contemporânea, 2(1), 101-125.

Sirdeshmukh, D., Singh, J., \& Sabol, B. (2002). Consumer Trust, Value, and Loyalty in Relational Exchanges. Journal of Marketing, 66(1), 15-37. 
Teleco (2018). Market Share das Operadoras de Celular no Brasil. Disponível em: http://www.teleco. com.br/mshare.asp. Acesso em: 10 mai 2018.

Urdan, A. T., \& Zuñiga, M. K. H. (2001). Satisfação com assistência técnica e lealdade ao fabricante no ramo automobilístico. Revista de Administração de Empresas, 41(3), 20-30.

Vasconcelos, F.C. \& Cyrino, A. B. (2000). Vantagem Competitiva: os modelos teóricos atuais e a convergência entre estratégia e teoria organizacional. Revista de Administração de Empresas, 40(4), 20-37.

Veja (2015, Feb, 2). Setor de telefonia lidera lista de reclamações em 2014.

Wu, L. (2011). Inertia: Spurious Loyalty or Action Loyalty? Asia Pacific Management Review, 16(1), 31-50.

Yanamandram, V., \& White, L. (2004). Why Customers Stay? Reasons and consequences of inertia in financial services. Managing Service Quality, 14(2/3), 183-194.

Yanamandram, V., \& White, L. (2006). Switching Barriers in Business-to-Business Services: a qualitative study. International Journal of Service Industry Management, 17(2), 158-192.
Yanamandram, V., \& White, L. (2007). A Model of Customer Retention on Dissatisfied Business Services Customer. Managing Service Quality, 17(2), 298-316.

Young, H. D. \& Freedman, R. A. (2008). Física. Vol 1: Mecânica. 12a ed. São Paulo, Person. Ch. 4.

Zacharias, M. L. B., Figueiredo, K. F., \& de Almeida, V. M. C. (2008). Determinantes da satisfação dos clientes com serviços bancários. $R A E$ eletrônica, $7(2)$.

Zeelenberg, M., \& Pieters, R. (2004). Beyond Valence in Consumer Dissatisfaction: a review and new findings on behavioural responses to regret and disappointment in failed services. Journal of Business Research, 57(4), 445-455

Zeithaml, V. A., Bitner, M. J. (2003). Marketing de Serviços: a empresa com foco no cliente. Porto Alegre: Bookman,

Zeithaml, V. A., Berry, L. L., \& Parasuraman, A. (1993). The Nature and Determinants of Customer Expectations of Service. Journal of the Academy of Marketing Science, 21(1), 1-12. 


\section{Appendix - Questionnaire}

Overall, what is your level of satisfaction with your current supplier?

(1) Very dissatisfied (2) Dissatisfied (3) Satisfied (4)Very satisfied

Market Isomorphism - (1) very different and (7) very similar.

1. How does your current supplier compare with others in terms of overall helpfulness of the supplier's agent?

2. How does your current supplier compare with others in terms of overall cost?

3. How does your current supplier compare with others in terms of the quality of the calls you make and receive?

4. If your current supplier has a physical store, how does it compare with other phone stores you may have seen?

5 . How does your current supplier compare with others in terms of signal coverage (in general, are there problem areas)?

6. How does your current supplier compare with others in terms of the range of equipment on offer?

7. If there are physical stores, how do you rate their layout?

8. How does your current supplier compare with others in terms of its complaints handling procedure?

9. How does your current supplier compare with others in terms of call charges?

10.How does your current supplier compare with others in terms of the accuracy of bills?

Perceived Service Quality - 1 is poorer than expected and 7 is exactly what you expected.

1. Overall performance of supplier's agent

2. Overall cost

3. Quality of the calls you make and receive

4. Physical appearance of the store

5. Signal coverage

6. Variety of equipment available

7. Store layout

8. Complaints handling procedures

9. Call charges

10. Accuracy of bills

Unattractiveness of Alternatives - 1 is strongly disagree and 7 is strongly agree

1. All the providers are the same

2. If I change my provider, I'm not sure about the results.

3. If I change my provider, I will continue having problems.

4. In my opinion, there aren't any other better providers.

5. Overall, the service from other providers will not be better.

Switching Barriers - 1 is strongly disagree and 7 is strongly agree

1. The time it would take to switch would be too great.

2. The effort to switch would be too great.

3. I'm concerned about financial losses

4. It would cause me too much hassle to change provider.

5. If I change provider, I have to learn a new routine and practices.

6. I feel locked in.

Switching Avoidance - 1 is strongly disagree and 7 is strongly agree

1. Overall, I avoid changing service providers.

2 . It is very tiring seeking other providers.

3. It is very tiring carrying out costs research.

4. Usually I prefer to keep my current service provider.

5. I rarely complain about service providers.

6. I'm too lazy to look for another service provider.

1. I intend to remain with my service provider.

Inertia - 1 is strongly disagree and 7 is strongly agree

2. Even if I have a problem, I will continue with this service provider.

3. Unless I have a very serious problem, I will continue with this service provider.

4. Unless another provider makes very attractive offers, I will continue with my current provider.

5. Overall, I would recommend this service provider to my family.

6. Overall, I would recommend this service provider to my friends. 
About the Authors:

1. José Marcos Carvalho de Mesquita, Doctor, Universidade Federal de Minas Gerais, Belo Horizonte, Brazil. E-mail: josemcmesquita@gmail.com

ORCID

iD 0000-0001-5897-1537

2. André Torres Urdan, Doctor, Universidade de São Paulo, São Paulo, Brazil. E-mail: andre.torres@uni9.pro.br ORCID

iD 0000-0002-4816-0973

\section{Contribution of each author:}

\begin{tabular}{lcc}
\hline Contribution & $\begin{array}{c}\text { José Marcos } \\
\text { Carvalho de Mesquita }\end{array}$ & André Torres Urdan \\
\hline $\begin{array}{l}\text { 1. Definition of research problem } \\
\text { 2. Development of hypotheses or research questions (empirical studies) }\end{array}$ & $\sqrt{ }$ \\
3. Development of theoretical propositions (theoretical work) & $\sqrt{ }$ \\
4. Theoretical foundation/Literature review & \\
5. Definition of methodological procedures & \\
6. Data collection & $\sqrt{ }$ \\
7. Statistical analysis & \\
8. Analysis and interpretation of data & \\
9. Critical revision of the manuscript & $\sqrt{ }$ \\
10. Manuscript writing & \\
11. Other (please specify which) & \\
\hline
\end{tabular}

